\title{
Labour
}

Journal of Canadian Labour Studies

Le Travail

Revue d'Études Ouvrières Canadiennes

\section{Back-to-Work Legislation Roundtable: Introduction}

\section{Charles Smith}

Volume 86, automne 2020

URI : https://id.erudit.org/iderudit/1074475ar

DOI : https://doi.org/10.1353/1lt.2020.0039

Aller au sommaire du numéro

Éditeur(s)

Canadian Committee on Labour History

ISSN

0700-3862 (imprimé)

1911-4842 (numérique)

Découvrir la revue

Citer ce document

Smith, C. (2020). Back-to-Work Legislation Roundtable: Introduction. Labour

Le Travail, 86, 107-108. https://doi.org/10.1353/llt.2020.0039 d'utilisation que vous pouvez consulter en ligne.

https://apropos.erudit.org/fr/usagers/politique-dutilisation/ 


\title{
PRESENTATION / PRÉSENTATION
}

\section{Back-to-Work Legislation Roundtable}

\author{
Introduction \\ Charles Smith, University of Saskatchewan
}

In 1984, LeO PANitch AND Donald Swartz published an article in the pages of this journal examining the coercive role that Canadian governments were playing in the restriction of workers' ability to strike. ${ }^{1}$ In that piece, Panitch and Swartz highlighted the "generalized rule-of-law form of coercion," which was tied to the restrictions of the postwar form of industrial legality, yet they noted that what was occurring in the 1970s and 1980s was "a form of selective, ad hoc, discretionary state coercion (whereby the state removes for a specific purpose and period the rights contained in labour legislation)."2 In their later book-length version of this article, Panitch and Swartz tracked the contradictory manner by which both federal and provincial governments repeatedly used so-called temporary measures to restrict workers' capacities to freely bargain and strike whenever such actions became economically or politically problematic for the state and the ruling classes. ${ }^{3}$ The authors were equally perplexed by the fact that the newly minted Charter of Rights and Freedoms' protection of freedom of association was interpreted by conservative judges to exclude either the right of workers to bargain or the right to strike. ${ }^{4}$ By 2003, these ad hoc restrictive measures and the state's disdain for workers' collective rights were so frequent that it was safe to say that Panitch and Swartz's

1. Leo Panitch \& Donald Swartz, "Towards Permanent Exceptionalism: Coercion and Consent in Canadian Industrial Relations," Labour/Le Travail 13 (Spring 1984): 133-157.

2. Panitch \& Swartz, "Towards Permanent Exceptionalism," 149.

3. Leo Panitch \& Donald Swartz, The Assault on Trade Union Freedoms: From Consent to Coercion Revisited (Toronto: Garamond, 1988).

4. Leo Panitch \& Donald Swartz, From Consent to Coercion: The Assault on Trade Union Freedoms (Toronto: Garamond, 2003). 
concept of "permanent exceptionalism" had become the new norm for all workers whose strike action threatened the political or economic status quo.

Recognizing the importance of Panitch and Swartz's groundbreaking examination of back-to-work legislation and the state's continuing usage of such legislative tools on Canadian workers, the Canadian Association for Work and Labour Studies (CAWLS) convened a panel at its 2019 annual meeting to discuss and examine what back-to-work legislation meant in the current era. The timing was particularly noteworthy given the fact that the Supreme Court of Canada had done an about-face on the collective rights of workers protected by the Charter, ruling in 2007 that there was a Charter-protected right to collectively bargain and in 2015 that workers had a collective right to strike. ${ }^{5}$ Yet, governments across the political spectrum, most recently by the Justin Trudeau Liberals in 2018, continued to use back-to-work legislation to end politically or economically inconvenient strikes. ${ }^{6}$ In order to address the conundrum that workers maintained rights both in statute and in the constitution yet continued to be subjected to state repression in actually exercising those rights, Christo Aivalis, Eric Tucker, Alison Braley-Rattai, and I have written these short essays to reflect on the legacy of Panitch and Swartz's examination of the Canadian government's ongoing usage of back-to-work legislation. At the heart of these essays are questions about the history of the legislation, the role of the constitution in protecting workers' rights, and the future of workers' struggles in Canada. If a common theme exists among these papers it is the quagmire that Canadian labour law and the Canadian constitution seemingly hinder as much as protect workers in exercising their basic rights to collectively bargain and to strike.

In each of the essays presented below, the author attempts to grapple with this tension. My and Aivalis' pieces are designed to place the ongoing usage of back-to-work legislation in historical context, examining the first use of the legislation in 1950 and how the Liberal government of Pierre Elliot Trudeau seemingly consolidated that usage in the 1970s and early 1980s, respectively. Meanwhile, Tucker and Braley-Rattai in turn examine the thorny issue of the Supreme Court of Canada's recent jurisprudence that constitutionalizes the rights of labour to bargain and strike yet does not seem to hinder governments in continuing to legislate workers back to work. Taken as a whole, these essays are designed to spark interest in and debate about the current regime of industrial legality while critically examining how the organized working classes work to mitigate the benefits and the costs of state regulation in the age of neoliberalism.

5. Health Services and Support - Facilities Subsector Bargaining Assn. v British Columbia, 2007 SCC 27, [2007] 2 SCR 391; Saskatchewan Federation of Labour v Saskatchewan, 2015 SCC 4, [2015] 1 SCR 245.

6. Charles Smith \& Larry Savage, "Back-to-Work Legislation May Come Back to Haunt Justin Trudeau," The Conversation, 6 December 2018, https://theconversation.com/ back-to-work-legislation-may-come-back-to-haunt-justin-trudeau-107779. 